\title{
Introduction: Environmental History and the History of Biology
}

\author{
LIBBY ROBIN \\ Fenner School for Environment and Society \\ The Australian National University \\ Canberra, ACT 0200 \\ Australia \\ E-mail: libby.robin@anu.edu.au \\ Centre for Historical Research \\ National Museum of Australia \\ Canberra, ACT 2600 \\ Australia
}

\section{JANE CARRUTHERS \\ Department of History \\ University of South Africa \\ Pretoria, Gauteng 0003 \\ South Africa \\ E-mail:Carruej@unisa.ac.za}

We are delighted to have been commissioned by Paul Farber, the general editor of the Journal of the History of Biology, to edit this special issue on Environmental History. This is a field of history which has long been acknowledged to have strong links with the biological sciences, in particular with conservation biology and ecology, and with other branches of biology as well. Our brief in editing this issue of the Journal of the History of Biology is to consider the shared boundaries by the two fields of history and we believe that the articles in this issue will surely illuminate some of them. A closer reading of the environmental history literature can enrich many aspects of the history of biology and, naturally, vice versa. We hope that this special issue will encourage regular readers of this journal to make a foray into the field of environmental history, enriching it with an even firmer base in the history of biology.

Environmental history is notoriously difficult to define. Take for example the title of Douglas Weiner's 2005 article in Environmental History, written as he ended his term as President of the American 
Society of Environmental History, "A death-defying attempt to articulate a coherent definition of environmental history." "An anniversary forum in Environmental History entitled "What's next for environmental history" showcased thirty viewpoints of leading practitioners, revealing that environmental historians prefer broad and inclusive definitions to narrow "boundary setting" and perhaps have a greater predilection for "futures" than other historians, as suggested by the forum's title. ${ }^{2}$ The interdisciplinarity of environmental history is both a strength and an anxiety for practitioners. Sörlin and Warde urge environmental historians to engage more critically in the understanding of the social context of biology and other knowledge systems. ${ }^{3}$ History and Theory carried a special issue on environmental history at the end of 2003 that appeared to accord the field theoretical imprimatur and recognition. ${ }^{4}$ Cultural historian Peter Burke concurs with this. He has stated that it has moved through the relevant phases of pioneering and consolidation, and now demonstrates that it has reached the age of "synthesis,", a judgment that might apply just as well to the history of biology. Environmental history is currently served with two international scholarly journals, the US-based Environmental History (which began under another name in 1975) and the UK-European based Environment and History (first published in 1999). ${ }^{6}$

Perhaps more than has been the case with the history of biology, the attention of the public has been propelled to take heed of environmental history through a concatenation of social and political interest, a burgeoning popular literature and current environmental concerns. Certainly, the birth of environmentalism as a strong global social movement with different forms in different parts of the world since the 1960s has contributed to its popularity and social profile. Popular writers such as Jared Diamond (himself a biologist) - with his books Guns, Germs and Steel 1998 and Collapse 2005 - have excited general interest in the topic, and the focus on global climate change also

1 Weiner, 2005, pp. 404-420.

${ }^{2}$ Environmental History, 2005, pp. 30-109. In this special section twenty-nine prominent environmental histories from diverse subject fields and parts of the globe summarized their impressions about possible future directions for environmental history.

3 Sörlin and Warde, 2007, pp. 107-130.

${ }^{4}$ History and Theory, 2003.

${ }^{5}$ Cited in Sörlin and Warde, 2009, p. 350.

${ }^{6}$ A third journal, Global Environment (established in Italy in 2008), carries the subtitle A History of Natural and Social Sciences. 
demands engagement with history. ${ }^{7}$ The Darwin bicentenary celebration of 2009 was another catalyst in the public's engagement with environmental history because it was, of course, Charles Darwin who put history into biology with his daring idea that nature was not immutable, it was - in fact - history, exhibiting change over time.

Essentially, environmental history interrogates how arenas that have traditionally been termed "nature" and "culture" interweave with one another in different places and at different times to create an "environment." It is not an homogenous discipline with a strong topical thread or even a coherent body of knowledge. It is thus somewhat broader than the history of biology, which, one might argue, deals with certain defined aspects of this wider cultural canvas. A recent book defines environmental history as explicitly "history" and thus "belonging in the humanist tradition of studying complex phenomena with respect for humans as, ultimately, persons with intentions and morals, and belonging in the realm of the polity." 8 Australian Tom Griffiths has argued that the very benefit of environmental history is that it prioritizes the "historians' traditional concerns of identity, agency, economy and politics" using the narrative form. ${ }^{9}$ These remarks might apply equally well to the history of biology as the range of articles appearing over the years in the Journal of the History of Biology attest. It is, however, somewhat surprising that environmental history is such a newcomer in the constellation of historical fields. For example, influential historian Donald Worster has persuasively argued that environmental history should be accepted as central to the discipline as a whole. He does not even consider that it is one of many equal historical fields, but one absolutely pivotal to understanding the past because it accepts that human life on earth has a historical spatial as well as a temporal dimension. ${ }^{10}$

As Brian Fay expressed it, "Historians have always known that the natural environment plays a significant role in how humans behave ... How could it be otherwise, given that human are biological creatures through and through, in constant interchange with their natural environment?" "11 No doubt Leopold von Ranke's insistence on the primacy of the political realm and the manuscript documentary source retarded the inclusion of the natural world in human affairs and thus

\footnotetext{
7 Robin and Steffen, 2007.

8 Sörlin and Warde, 2009, p. vii.

9 Griffiths, 2002, pp. 376-378.

${ }^{10}$ Quoted in White, 1990, p. 1111.

11 Fay, 2003, p. 1.
} 
environmental history's emergence as a distinct field, but other disciplines took on its role until it found its own name. Environmental history certainly had strong academic antecedents in historical geography and in economic history, particularly in the work of the Annales, European scholars who wrote an exciting new form of "total history" in the early twentieth century. We also have to recognize the scholarly trajectory from the work of Californian cultural geographer Carl Sauer and his British counterpart W.H. Hoskins, together with Clarence Glacken's Traces on the Rhodian Shore. ${ }^{12}$ Environmental history continues to thrive in geography departments in Britain, New Zealand and Canada, but elsewhere the geographers themselves have often moved into interdisciplinary units of "environmental studies," as is the case in Australia and Scandinavia where environmental history is nurtured alongside policy analysis and applied science. As will be observed in this journal issue, two of the contributors, Laura Cameron and David Matless, are geographers.

In view of our own geographical positioning, one of our purposes has been to introduce environmental history from a non-North American or European perspective. In many parts of the developing world, such as India, Africa, South Asia and South Africa, environmental history was brought to bear through agricultural and social history and in postcolonial studies of imperialism. In Africa specifically, environmental history originated from a strong African social history paradigm that had much to do with environmental justice. ${ }^{13}$ Unfortunately, we were unsuccessful in soliciting papers from or about Africa generally, or India, or the Far East, but we have been able to represent work about Australia and southern Africa, and the relations between them. In Australia, the "network" of about 200 self-identified environmental historians and interested parties comprises a large number of ecologists and geomorphologists, policy analysts and foresters, alongside historians. Practical scientists are an important part of the group. Studying air pollution or the medical industry for their historical environmental effects, for example, requires expert knowledge of chemical composition, as the books by Nancy Langston and Joel Tarr (to give just two examples) demonstrate so well. ${ }^{14}$ Links between environmental history and ecological science are even closer, it may be argued, and historical ecology (or ecological history) - at least in much of the literature in

12 Sauer, 1925, pp. 19-53; Glacken, 1967; Hoskins, 1970; McNeill, 2003, pp. 5-43.

13 Taylor, 1996, pp. 6-19; Beinart and McGregor, 2003; Beinart, 2000, pp. 269-302; Carruthers, 1996, pp. 125-138, 2004, pp. 379-406; McCann, 1997, 1999.

14 Langston, 2010; Tarr, 1996. 
Australia and Africa - vies for the claim to be referred to as "environmental history." This may be so because so much of the past of these regions of the world remains in the field of archaeology (once referred to as pre-history) rather than in the written record. ${ }^{15}$ As Sterling Evans observed in his review of William Balee's Advances in Historical Ecology 1998, "The can of worms between environmental history and historical ecology is now officially opened ... The similarity in scope between these two disciplines is seen in the publisher's explanation ... [that historical ecology aims to] ... 'explore the complex links between people and the landscapes that both molded individuals and societies and are fashioned by them." "Landscape" and human interaction with it are integral concepts in historical ecology and we thought it important to include an example of such a study here (see Hoffman and Rohde).

It was, however, in the United States America that environmental history first emerged as a named and taught academic discipline and initially it was strongly influenced by the environmental protest movement of the 1960s and 1970s. Its influence has been to project the environment not merely as the stage upon which human history has played out, but as an agent integral to the drama. ${ }^{17}$ Richard Grove and other historians of empire took environmental history further back into the past by generating a rich literature of the environmental interactions that made imperialism both possible and successful. ${ }^{18}$ Environmental history has taken many forms over the past few decades. In History and Theory, John McNeill "shows the ways that environmental history is itself shaped by political and cultural concerns" that vary in different parts of the world - as will become evident from the articles included here. ${ }^{19}$ This form of history has been the major catalyst for suggesting and providing connections between the pasts of different biological and physical places in the world. It has created fresh intellectual links in regional, national and world histories, and it has invigorated and reconfigured much of our understanding about connections between the periphery and the metropole, the developing and developed world, and between traditional disciplinary boundaries. Refracting our

15 Smith and Hesse 2005; Shetler, 2007; Historical Ecologies of East African Landscapes (HEEAL), http://www.heeal.eu.

16 Evans, 1999, p. 287.

17 Worster, 1988; Crosby, 1995, pp. 1177-1189; White, 1985, pp. 297-337; Nash, 1972, pp. 362-372; Stewart, 1998, pp. 351-368; Steinberg, 2002, pp. 798-820; Hughes, 2006.

18 Grove, 1995; MacKenzie, 1988, 1990; Beinart and Hughes, 2007.

19 Quoted in Fay, 2003, p. 1. 
understanding about the past through the prism of the environment around us has added excitement and relevance to modern historical studies generally, and encouraged innovative research in many previously neglected areas of study.

There are two significant characteristics linking the history of biology and environmental history that emerge especially from the articles in this special issue. The first is the transnational, or global, nature of the field, and the second is its relationship to science.

Certainly environmental history resonates with the national perspective depending on the study area and scholarly community. For example, in the case of Australia, the dominating concern is how European settlers came to terms scientifically, aesthetically, economically and politically with an unusual and strangely fragile landscape and biota, peopled by Aboriginal Australians with strong links to the "country" that shapes their identity and nurtures their existence. ${ }^{20}$ New Zealand has an important contribution to make because of the speed of ecological transformation there, ${ }^{21}$ while South Asian environmental history is characterized by investigating the nature and significance of the colonial experience, related particularly to agrarian history. ${ }^{22}$ On the other hand, European environmental history is rooted in landscape and urban history and the management of agricultural land. ${ }^{23}$ Martin Carey summarizes Latin American environmental history as being concerned with "colonialism, capitalism and conservation" 24 and in many respects this applies to African environmental history too. Much of the literature concerns the colonial encounter, the rise of modern industrialization and jettisoning notions of an "untouched" wilderness. ${ }^{25}$

Nonetheless of all the historiographies, environmental history cannot be divorced from transnational concerns, ${ }^{26}$ and Klingle rightly suggests that there is an "artificial split between the local and the global" which environmental history attempts to bridge. ${ }^{27}$ The very arrangement of the disciplinary coordinating body currently reflects this, with the recent

20 Robin, 1998, 2007; Robin and Griffiths, 2004, pp. 439-474; Pawson and Dovers, 2003, pp. 53-76.

21 Brooking and Pawson, 2003.

22 Rangarajan, 1996, pp. 129-143; for distinctions between US and Asian environmental history see Sutter, 2009, pp. 543-550.

${ }^{23}$ Ford, 2007, pp. 112-133; Cioc et al., 2000, pp. 396-406.

${ }^{24}$ Carey, 2009, pp. 221-252.

25 McCann, 1997, pp. 138-159; Duffy, 2000; Adams and McShane, 1996; Dovers et al., 2003.

${ }^{26}$ Irirye and Saunier, 2009; Beinart and Coates, 1995; Dunlap, 1999; Tyrrell, 1999.

27 Klingle, 2003, p. 108. 
establishment of the International Consortium of Environmental History Organizations that took responsibility for arranging the first World Congress of Environmental History, held in August 2009. Even the conference itself traveled internationally, being shared between Copenhagen, Denmark and Malmö, Sweden, with joint hosts Roskilde University, Malmö University and the International Consortium.

The reason for the strong thrust in transnational environmental history is that natural resources take no heed of national boundaries and environmental history raises issues that communities and cultures, often embedded in what might be termed "bioregions," have in common. Seminal to the debate has been the work of Alfred Crosby whose book, Ecological Imperialism: The Biological Expansion of Europe, 9001900 (published in 1986), first alerted historians' attention to the importance of travelling biota. ${ }^{28}$ Building on Crosby's work, but relating it specifically to British imperialism and inter-colonial connections, is the well-documented article by Brett Bennett, "A Global History of Australian Trees." This piece relies on the literature of botany, in terms of biology, but also questions agency and provides a nonEurocentric perspective to what has been a truly transnational biological phenomenon. Bennett focuses on transplanting Australian biota, particularly tree species that proved useful to the imperial enterprise, reminding historians of biology (as well as invasion biology botanists) that an understanding of global socio-economics and political power relations cannot be absented from the history of nature.

The article by Laura Cameron and David Matless (both geographers), "Passing for the 'natural': The Norfolk Broads and the International Phytogeographical Excursion, 1911," discusses ecological transnationalism more generally on the one hand, but more specifically on the other. Their subject - the first IPE excursion to the Norfolk Broads that led to the foundation of the British Ecological Society, and thereafter to many important ecological conversations (some of them contentious) across the Atlantic - may be familiar to historians of ecology, though probably not to those in other fields of the history of biology. As well as marking an important point in time and in a particular space, Cameron and Matless add a significant gender dimension to the history of ecology through their introduction of a little known British woman ecologist, Marietta Pallis, enriching it with a number of personal textual accounts that consider the relation between her work and that of American ecologists. The central question of the article is,

${ }^{28}$ See interview of Alfred Crosby by Cioc and Miller in Environmental History, 2009, pp. 559-568. 
however, framed as "environmental history." They ask: How natural were the Norfolk Broads? How is "naturalness" constructed and how does it shape the ecological science that builds on this construction? As others have done, they conclude that "nature" is a cultural product, whether it pertains to the agriculturally and water-rich European landscape, Australian Aboriginal firestick farming and care for "country," or the savannas of Africa that were also manicured by fire and pastoralism. This paper is also symbolically important in the history of environmental history: a shorter version of it was presented as the first paper in Session 1 at the 2009 World Congress in Environmental History, mentioned above.

While we are extremely pleased to be able to present the work of a younger generation of scholars in the field of environmental history, it is an equal pleasure to include a brief reflective "think piece" by J. Donald Hughes, one of our doyens and the John Evans Distinguished Professor and Professor Emeritus of History at the University of Denver. In "Ancient deforestation revisited," Hughes also takes vegetation, and thus botany, as his biological theme. Like Cosgrove, Hughes's interests are broad and visual, and he has written extensively on world environmental history, the history of the Graeco-Roman world and the environmental history of the Oceanic Pacific Islands. ${ }^{29}$ The article included here responds to a specific debate in environmental history: "How forested was the Mediterranean world, how much damage was done to forests in classical times, and what effect did deforestation have on ancient societies?" Using paintings, together with the most up-todate botanical techniques in anthrocology, palynology and computer modeling, Hughes's succinct article posits the tensions between historians and scientists in a dramatic fashion. However, it also involves the dimension of value judgments, in terms of whether anthropogenic environmental change is "good" or "bad."

Hughes's discussion of what the biological sciences can offer to environmental historians brings us to the second main theme of this special issue, the relationship between environmental history and science. In their introduction to the 1994 special issue on immunology in this journal, Alberto Cambrosio, Peter Keating and Alfred I. Tauber expressed their concern over a symposium held the previous year. The gathering was ostensibly convened to bring "together scientists and professional historians engaged in conceptual issues in immunology," in an attempt to "exchange ideas across disciplinary boundaries" ... [but it] ... had seemed to several of the participants, however, that the

29 Hughes, 1975, 1994, 2001, 2005, 2006. 
"exchange" was meant to be unidirectional: scientists engaged in the production of immunological knowledge were there to tell historians "how things had really been." 30 There are many environmental historians who would share and entirely sympathize with the experience of these historians of immunology. Nonetheless, perhaps the most important connection that both environmental history and the history of biology might make is to elide what C.P. Snow in 1959 famously called the "two cultures," which has - as is well known - become an industry in itself, spawning a seemingly endless plethora of books and articles. ${ }^{31}$ Donald Worster has said that environmental history has the potential to close the gap between the humanities and the sciences, the environmental sciences in particular, and we would go further to suggest that the history of biology has a similar role to play. Worster has referred to the process as looking for common ground, of finding "open doorways through the walls of specialization that divide us ... We are opening a door in the wall that separates nature from culture, science from history, matter from mind. Where we are arriving is not at some point where all academic boundaries and distinctions disappear... but one where those boundaries are more permeable than before." ${ }^{32}$ Sörlin and Warde also allude to the connection as not being the promotion of full inter- or multi-disciplinarity, but to a "translatory role between disciplines." 33

Four authors, Etienne Benson, environmental historian, Karen Brown, historian of medicine, Timm Hoffman, a botanist, and Rick Rohde, a social anthropologist, have adopted this vision in the work presented here. Benson's "A difficult time with the permit process," explores the complex ramifications of the bureaucratic dimensions of biological research. In explaining how research scientists and affiliated technicians regarded the electronic tagging of bowhead whales in Alaska as an effective new tool to monitor whale populations and migrations, Benson points to the constraints that culture and history placed upon this scientific innovation and on conservation biology in this period and place. His archival research is meticulous and extensive and makes a contribution to the understanding of conservation biology. Not only were there fractious indigenous politics and animal rights lobbies to be placated, but the author deftly explains the complex and politically contested world of field biology that emerged in the 1970s.

30 Cambrosio et al. 1994, pp. 375-378.

31 Wilson, 1998; Gould, 2003; Worster, 1996 - to name just three.

32 Worster, 1993, pp. 4, 13.

33 Sörlin and Warde, 2007, p. 118. 
The "permit process," it seems, was all-important, but woven into it was, nevertheless, the shaping of marine mammal research, a biological science that has become even more important with expanding knowledge about global climate change.

Brown's account of "Rabid epidemiologies: The emergence and resurgence of rabies in twentieth-century South Africa" narrows the spatial frame directly into the South and also into the history of animal biology. South African veterinary biology has a long history and Brown is the acknowledged authority on many of its aspects. Indeed, the history of disease, it might be argued, was environmental even as it predated the formulation of the field of "environmental history" into which it has become incorporated. Epidemiology and public health issues are vital to many communities in Africa and Brown's account thus demonstrates a non-American definition of environmental history. The article begins with the tragic deaths of two South African teenagers in rural South Africa who expired extremely painfully from rabies in the early twentieth century. From this event, she broadens her narrative into an analysis of the history and epidemiology of rabies in the southern African subcontinent, showing how powerfully context and general historical understanding can add value to the science of the disease. Moreover, she and Benson - and unlike the experience of the immunology symposium mentioned above - are historians telling scientists "how things really have been".

Hoffman and Rohde's article is the most strongly "scientific" in the collection and it may be more familiar to biologists than environmental history, which has been directly influenced by cultural studies. It is botanical in direction, and it speaks to the theme that science is timebased and locale-based. Their dramatic visual and descriptive recording of changing ideas in botanical science because of the history of the plants that they study and their dramatic recording of landscape alteration with passing decades marks an important point in bringing history and botany together. Older photographic landscape records are rare in South African history and the authors have drawn on unusual archival sources to illustrate their arguments. Their study area, the remote, botanically unusual and aesthetically challenging arid region of South Africa's Northern Cape Province, is generally understudied but ideas around climate change and the alterations in species composition and plant cover in river systems is the particular merit of this paper. This article is a fine example of historical ecology - as discussed above firmly anchored in the natural sciences and attuned to both anthropogenic and non-anthropogenic change over time. 
We are sure that there are historians of biology who will be interested in the articles in this issue and perhaps there are scholars who would identify themselves as both historians of biology and environmental historians. Yet, surprisingly, there has been little exploration of the shared interests of our two groups. In this volume we cannot hope to be exhaustive, but we have ventured a small selection of some of the new writing in the field, and it reflects many of its silences, as well as demonstrating some of its "hotspots." It is our hope that historians of biology will be inspired to respond with a similar collection in an environmental history journal in order to maximize scholarship in our collaborative disciplinary endeavor and, indeed, introduce invigorating new debate and fresh directions to follow.

\section{References}

Adams, Jonathan S. and McShane, Thomas O. 1996. The Myth of Wild Africa: Conservation without Illusion. Berkeley etc.: University of California Press.

Balee, William (ed.). 1998. Advances in Historical Ecology. New York: Columbia University Press.

Beinart, W. 2000. "African History and Environmental History." African Affairs 99: 269-302.

Beinart, William and Coates, Peter. 1995. Environment and History: The Taming of Nature in the USA and South Africa. New York: Routledge.

Beinart, William and Hughes, Lotte. 2007. Environment and Empire. Oxford: Oxford University Press.

Beinart, William and McGregor, JoAnn (eds.). 2003. Social History and African Environments. Oxford: James Currey.

Brooking, Tom and Pawson, Eric. 2003. "Editorial: New Zealand Environmental Histories." Special issue: New Zealand, Environment and History 9(4).

Cambrosio, Alberto, Keating, Peter and Tauber, Alfred I. 1994. "Introduction: Immunology as a Historical Object." Journal of the History of Biology 27(3): 375-378.

Carey, Mark. 2009. "Latin American Environmental History: Current Trends, Interdisciplinary Insights, and Future Directions." Environmental History 14: 221-252.

Carruthers, Jane. 1996. "Nationhood and National Parks: Comparative Examples from the Post-Imperial Experience." T. Griffiths and L. Robin (eds.), Ecology and Empire: Environmental History of Settler Societies. Edinburgh: Keele University Press, pp. $125-138$.

— 2004. "Africa: Histories, Ecologies and Societies." Environment and History 10: 379-406.

Cioc, Marc, Linnér, Bjōrn-Ola and Osborn, Matt. 2000. "Environmental History Writing in Northern Europe." Environmental History 5(3): 396-406.

Cioc, Marc and Miller, Char. 2009. "Interview: Alfred Crosby." Environmental History 14(3): 559-568. 
Crosby, Alfred W. 1986. Ecological Imperialism: The Biological Expansion of Europe, 900-1900. Cambridge: Cambridge University Press.

Crosby, Alfred W. 1995. "The Past and Present of Environmental History." American Historical Review 100: 1177-1189.

Diamond, Jared. 1998. Guns, Germs and Steel: A Short History of Everybody for the Last 13000 Years. London: Vintage.

Diamond, Jared. 2005. Collapse: How Societies Choose to Fail or Survive. London: Allen Lane.

Dovers, Steven, Edgecombe, Ruth and Guest, Bill (eds.). 2003. South Africa's Environmental History: Cases and Comparisons. Athens: Ohio University Press.

Duffy, Rosaleen. 2000. Killing for Conservation: Wildlife Policy in Zimbabwe. Oxford: James Currey.

Dunlap, Thomas R. 1999. Nature and the English Diaspora: Environment and History in the United States, Canada, Australia, and New Zealand. Cambridge: Cambridge University Press.

Environmental History. 2005. "Anniversary Forum: What's Next for Environmental History?" 10(1): 30-109.

Evans, Sterling. 1999. "Review of Advances in Historical Ecology." Environmental History 4: 287-288.

Fay, Brian. 2003. "Environmental History: Nature at Work." History and Theory 42: $1-4$.

Ford, Caroline. 2007. "Nature's Fortunes: New Directions in the Writing of European Environmental History." The Journal of Modern History 79: 112-133.

Glacken, Clarence J. 1967. Traces on the Rhodian Shore. Berkeley: University of California Press.

Gould, Stephen Jay. 2003. The Hedgehog, the Fox, and the Magister's Pox: Mending and Minding the Misconceived Gap Between Science and the Humanities. London: Jonathan Cape.

Griffiths, Tom. 2002. "How Many Trees Make a Forest? Cultural Debates About Vegetation Change in Australia." Australian Journal of Botany 50: 375-389.

Griffiths, Tom and Robin, Libby (eds.). 1997. Ecology and Empire: Environmental History of Settler Societies. Edinburgh: Keele University Press.

Grove, Richard. 1995. Green Imperialism: Colonial Expansion, Tropical Island Edens and the Origins of Environmentalism. Cambridge: Cambridge University Press.

History and Theory. 2003. Theme Issue "Environmental History: Nature at Work." 42: December.

Hoskins, W.G. 1970. The Making of the English Landscape. Harmondsworth: Penguin.

Hughes, Donald J. 1975. Ecology in Ancient Civilizations. Albuquerque, NM: University of New Mexico Press.

1994. Pan's Travail: Environmental Problems of the Ancient Greeks and Romans. Baltimore: Johns Hopkins University Press.

2001. An Environmental History of the World: Humankind's Changing Role in the Community of Life. London and New York: Routledge.

— 2005. The Mediterranean: An Environmental History. Santa Barbara, CA: ABCCLIO.

— 2006. What is Environmental History?. Cambridge, UK: Polity Press.

Irirye, Akira and Saunier, Pierre-Yves (eds.). 2009. The Palgrave Dictionary of Transnational History. Houndmills: Macmillan. 
Klingle, Matthew W. 2003. "Spaces of Consumption in Environmental History." History and Theory 42: 94-110.

Langston, Nancy. 2010. Toxic Bodies: Hormone Disruptors and the Legacy of DES. New Haven: Yale University Press.

MacKenzie, John M. 1988. The Empire of Nature: Hunting, Conservation and British Imperialism. Manchester: Manchester University Press.

MacKenzie, John M. (ed.). 1990. Imperialism and the Natural World. Manchester: Manchester University Press.

McCann, James. 1997. "The Plow and the Forest: Narratives of Deforestation in Ethiopia, 1840-1992." Environmental History 2(2): 138-159.

McCann, James. 1999. Green Land, Brown Land, Black Land: An Environmental History of Africa. Portsmouth: Heinemann.

McNeill, John R. 2003. "Observations on the Nature and Culture of Environmental History." History and Theory 42: 5-43.

Nash, Roderick. 1972. "American Environmental History: A New Teaching Frontier." Pacific Historical Review 41(3): 362-372.

Pawson, Eric and Dovers, Stephen. 2003. "Environmental History and the Challenges of Interdisciplinarity: An Antipodean Perspective." Environment and History 9(1): 53-76.

Rangarajan, M. 1996. "Environmental Histories of South Asia: A Review Essay." In Special issue: South Asia. Environment and History 2(2): 129-143.

Robin, Libby. 1998. Defending the Little Desert: The Rise of Ecological Consciousness in Australia. Melbourne: Melbourne University Press.

Robin, Libby. 2007. How a Continent Created a Nation. Sydney: University of New South Wales Press.

Robin, Libby and Griffiths, Tom. 2004. "Environmental History in Australasia." Environment and History 10(4): 439-474.

Robin, Libby and Steffen, Will. 2007. "History for the Anthropocene." History Compass 5(5): 1694-1719.

Sauer, Carl O. 1925. "The Morphology of Landscape." University of California Publications in Geography 2(2): 19-53.

Shetler, Jan B. 2007. Imagining Serengeti: A History of Landscape Memory in Tanzania from Earliest Times to the Present. Athens: Ohio University Press.

Smith, Mike and Hesse, Paul (eds.). 2005. 23 Degrees South: Archaeology and Environmental History of the Southern Deserts. Canberra: National Museum of Australia Press.

Sörlin, Sverker and Warde, Paul. 2007. "The Problem of the Problem of Environmental History: A Re-reading of the Field." Environmental History 12(1): 107-130.

Sörlin, Sverker and Warde, Paul (eds.). 2009. Nature's End: History and the Environment. Basingstoke: Palgrave Macmillan.

Steinberg, Ted. 2002. "Down to Earth: Nature, Agency and Power in History." The American Historical Review 107(3): 798-820.

Stewart, M.A. 1998. "Environmental History: Profile of a Developing Field." The History Teacher 31: 351-368.

Sutter, Paul. 2009. "When Environmental Traditions Collide: Ramachandra Guha's The Unquiet Woods and US Environmental History." Environmental History 14(3): 543-550.

Tarr, Joel A. 1996. The Search for the Ultimate Sink: Urban Pollution in Historical Perspective. Akron: University of Akron Press. 
Taylor, Alan. 1996. "Unnatural Inequalities: Social and Environmental History." Environmental History 1(4): 6-19.

Tyrrell, Ian. 1999. True Gardens of the Gods: Californian-Australian Environmental Reform, 1860-1930. Berkeley etc.: University of California Press.

Weiner, Douglas R. 2005. "A Death-Defying Attempt to Articulate a Coherent Definition of Environmental History." Environmental History 10: 404-420.

White, Richard. 1985. "American Environmental History: The Development of a New Historical Field." Pacific Historical Review 54: 297-335.

White, Richard. 1990. "Environmental History, Ecology and Meaning." In "A Round Table: Environmental History." Journal of American History 76(4): 1111-1116.

Wilson, Edward O. 1998. Consilience: The Unity of Knowledge. New York: Knopf.

Worster, Donald (ed.). 1988. The Ends of the Earth. New York: Cambridge University Press.

Worster, Donald. 1993. The Wealth of Nature: Environmental History and the Ecological Imagination. New York: Oxford University Press.

1996. "The Two Cultures Revisited: Environmental History and the Environmental Sciences." Environment and History 2(1): 3-14. 